\title{
Reflection of Feminism in Veronica Roth's Divergent
}

\author{
L. Dyah P. Wardani \& Dianita Prasetyo Ningrum, \\ Universitas Jember \\ (dyahpw.sastra@unej.ac.id)
}

\begin{abstract}
Reflection of feminism is seen through the statements, ideas, and behaviors in Divergent novel. It is depicted through its major female characters. Those characters show their power, strength, and bravery which are different with women in common. In this research, I use the theory of literature by Rene Wellek and Austin Warren which is used to analyze the characterization through the major female characters in the novel which are constructed by Veronica Roth. Then, feminism by Simone de Beauvoir is applied to know how the social status of those major female characters is and how they have reflected feminism. Finally, this analysis will show to the readers about women's power. The analysis of the reflection of feminism in Divergent novel shows women also have the same rights as men, and women are not always subjugated. According to statements, behaviors, and ideas of feminism in the novel, it is shown that every woman actually can choose whatever they want depending on their own desire.
\end{abstract}

Keywords: reflection, feminism, women's power, equal rights.

Women are usually considered less important than men due to many reasons. The most widely reason used to justify that women are not better than men is because of their biological state. It is because women are generally considered weaker than men. The biological weakness or inferiority of women is considered unchangeable in the society due to stigmatization. The society constructs gender idea to its members that men are stronger than women. This construction is based on the culture that privileges men by promoting traditional gender role. According to Tyson, traditional gender roles cast men as rational, strong, protective, and decisive. Whereas women cast as irrational, weak, nurturing, and submissive. These gender roles still occur today (2006).

Divergent tells about a woman as the main female character, Beatrice Prior or "Tris", who explores her identity according to five different factions that exist in her country. There are Abnegation, for the selfless; Amity, for the peaceful; Candor, for the honest; Dauntless, for the brave; and Erudite, for the intellectual. This novel shows how the struggle of Tris who is born 
into Abnegation family and as Divergent which means that she has so many varying personality traits that could belong to any number of factions.

On the other hand, there are also other major female characters that are written by Roth in her novel. These major main female characters play the important role in the novel such as Natalie Prior, Jeanine Matthew, and Christina. They are included in the category of superior women, and their characters are often demonstrated in the novel. All of them have different characters, but their characterization still shows the abilities of strong, brave, and resilient women.

The problem that will be discussed in this thesis is the reflection of feminism in the female characters in the novel. Therefore, these problems are formulated in three questions:

1) How are the female and male characters characterized in the novel?

2) How is the social status of the female characters in the novel?

3) How do the female characters reflect feminism?

\section{Method}

A qualitative research concerns with collecting and analyzing information to gain data. The primary data are facts and information about the discourse of masculinity that is represented in the novel. For reaching the goals of this research about the reflection of feminism in Veronica Roth's Divergent, there are several steps to analyze the novel by using the Rene Wellek and Austin Warren's theory and applying feminism by Beauvoir. The first step is to choose the topic. It is the reflection of feminism in Veronica Roth's Divergent. The second step is to do close reading related to materials about feminism to get more information related to the topic discussion about the reflection of feminism in Veronica Roth's Divergent. The third step is to classify and to categorize the data from novel which relate to the reflection of feminism in Veronica Roth's Divergent.

After getting the data and information, the next steps are analyzing how the major female characters are characterized in the novel. This step is done by finding out and explaining behaviors, manners, styles, and ways of communication of major main female characters and major main male characters. This step is made based on the story which is written in the novel.

Then, next step is analyzing the condition of the society in the novel to find out their social status in the novel. This step analyzes major female characters' jobs, actions, and 
activities. Therefore, this step also uses quotations from the novel as the proofs which are related to this discussion.

Furthermore, after knowing their characterization and their social status, I will connect those results to the theory of feminism by Simone de Beauvoir. In addition, library research is also applied by gathering the information about women problems and the data from several books in relation to the study. Finally, I will be able to prove that the major female characters in Divergent novel have reflected feminism.

\section{Result and Discussion}

\section{Defining Characterization of the Major Female Characters}

Every literary work has characters to develop its story. Here, every character is told differently based on the writers need. The characters have their own characterization to explain to the readers or audiences about their roles, actions, and behaviors in the literary works. According to Harrison, characterization is the concept of creating characters for a narrative (1998, p. 51). Characterization can be described directly or indirectly by the writers. In this subchapter, I will analyze the characterizations of the major female characters. There are Tris, Christina, Natalie, and Jeanine. These characters are very interesting to be analyzed because they play important roles in the novel. Their characterizations show the strength of women. They can get equal rights with men. Besides, they have different ability with the other women in general.

Tris' Characterization as the Main Female Character

Tris is one of the divergent people, and she knows it after finishing the aptitude test, the test that will show which of the factions they belong in. The test shows that she is able to choose three factions, Abnegation, Dauntless, and Erudite. This is very dangerous for Tris because people believe that divergent is people who will break their society, and Tris knows this situation when Tori, instructor in aptitude test, tells her about her test result. “.... I mean you should never share them with anyone, ever, no matter what happens. Divergence is extremely dangerous. You understand? (Roth, 2011, p. 20)".

However, she finally chooses Dauntless as her new faction. She proves it that she is brave to choose Dauntless. She becomes Dauntless initiate. Here, she starts to show her hidden power from doing dangerous things. It is because Dauntless faction is like armies, so they do many 
extreme actions. Men and women are learned how to use a gun. They also learn how to combat with the other initiates. However, Tris has no ability, and she also has small body and has no muscles. "My odds, as the smallest initiate, as the only Abnegation transfer, are not good (Roth, 2011, p. 44)". She thinks that these actions are too hard for a girl who has no ability like her.

I tell myself, as sternly as possible, that is how things work here. We do dangerous things and people die. People die, and we move on to the next dangerous thing. The sooner that lesson sinks in, the better chance I have at surviving initiation.

I'm no longer sure that I will survive initiation (Roth, 2011, p. 36).

Day by day Tris practices better than the first time she came to Dauntless faction. She has learned many things. She shows her power during the combat practice. She can defeat other initiate. She also helps Al when he is bullied by Eric. Tris is brave to help her friends that she fells right to be helped even she has to be against the leader instructor of Dauntless. This condition makes Tris become the strongest initiate in the Dauntless.

"Any idiot can stand in front of a target," I say. "It doesn't prove anything except that you're bullying us. Which, as I recall, is a sign of cowardice" (Roth, 2011, p. 89).

My name is in the first slot (Roth, 2011, p. 140).

She thinks that she is not capable of being strong, powerful and brave, but she always learns and changes. Every practice that she has learned makes her learning a lot about her power. It shows that women is able to become strong and powerful. They can choose what they want. They cannot become submissive anymore, and it can be realized when they always try as hard as they can to get their own choice.

Christina's Characterization as the second Major Female Character

Christina is Tris' new best friend in Dauntless faction. She is a Candor girl who also transfers to Dauntless faction. She is also specifically described as a black woman of color, pretty face, has a long nose, and tall. Because of her Candor upbringing, she can be very blunt and honest. "Sorry, am I being rude?" she asks. "I'm used to just saying whatever is on my mind. Mom used to say that politeness is deception in pretty packaging (Roth, 2011, p. 49)". This quote shows that she is used to say everything in her mind without any doubt even it can hurt other people's feeling. It is because she comes from Condor faction. Even she asks sorry in the end of 
her statement, she still cannot control her habit from her previous faction. Her words are still influenced by Condor thought. She believes saying the truth that hurts other people's feeling is better than saying lie words that only please the others because people need to know the truth even they will get hurt.

Christina is also brave and tough. When she fights with Molly in the combat test, she can not handle her. She says to Eric that she gives up and wants to end their fight. Then, Eric thinks that Christina's action is cowardice. He does not want Dauntless initiate becomes a coward. Finally, Eric tells Christina to hang over the chasm for five minutes, and Christina accepts it.

"Climb over the railing," says Eric again, pronouncing each word slowly. "If you can hang over the chasm for five minutes, I will forget your cowardice. If you can't, I will not allow you to continue initiation." ... "Fine," she says, her voice shaking (Roth, 2011, p. 59).

The quotation above shows that Christina wants to prove to Eric that she is not a coward. She accepts Eric's test to hang over the chasm even she knows that it is very dangerous for her because the chasm is slippery and cold. She may not be able to hold on, but she prefers doing it to prove her bravery than being a factionless.

Natalie's Characterization as the Third Major Female Character

Natalie is a mother who gives a lot of her love and care to her children in every condition. She can accept what her children want for their new faction. She can understand about their choices. She still gives much care even Tris decides to transfer to Dauntless, and Caleb decides to transfer to Erudite. She does not only encourage them that their decision is good but also continues to visit them and provides for them because she wants to keep her children safe wherever they are. It proves that she is care and kindhearted.

My selfless mother. She should not be giving me gifts, not after I left her and my father (Roth, 2011, p. 96).

"I don't care what faction you chose," she says, touching her hands to my cheeks.

"I am your mother and I want to keep you safe" (Roth, 2011, p. 101).

Her care is shown when Natalie knows that Tris is divergent. Then, she visits her in Dauntless in visiting day. She tells Tris to ask her brother, Caleb, to investigate the Erudite's simulation serum because this serum is dangerous. She also warns Tris about Jeanine who is watching all of her movements, and Tris should be careful about her Divergence because Jeanine 
is looking for divergent people to be killed. Jeanine believes that divergent people are dangerous for the society because they cannot be controlled. This is so out of sync with the rest of society that she refuses to be against divergent and put faction before blood. "You're my daughter. I don't care about the factions." She shakes her head" (Roth, 2011, p. 225). It shows that she loves her children very much. She still cares for her children no matter what they choose.

In addition, Natalie was also a Dauntless member. She takes out her Dauntless ability when Tris is in danger. She saves her from drowning in the tank and attempts to reach the sector where the surviving Abnegation are hiding. Then, she kills the soldiers who arrest Tris.

She pulls my arm across her shoulders and hauls me to my feet. She is dressed like my mother and she looks like my mother, but she is holding a gun, and the determined look in her eyes is unfamiliar to me. (Roth, 2011, p. 224).

She is a powerful mother figure. She builds Tris's courage to run as fast as she can into a crowd of soldiers then she will distract them. She knows that she might be killed, but it does not matter to her. In the end, she gets shot by one of the soldiers and dies.

"So," my father says quietly. "Where is your mother?"

...

"She's gone," I say. "She saved me."

...

"That is good," he says, sounding strained. "A good death" (Roth, 2011, p. 229)

Natalie sacrifices her life to save her daughter. It is believed as a good death because she dies for a good purpose. She dies like a warrior. She bravely protects her daughter from the danger. Her intentional desire is to keep Tris safe. She does not think about faction anymore. "You're my daughter. I don't care about the factions" (Roth, 2011, p. 225). It shows that all she does is based on her own desire. There is no compulsion from the other to do that. She lives as selfless, kindhearted, powerful, and strong mother in Tris' mind.

Jeanine's Characterization as the Fourth Major Female Character

Jeanine is the leader of Erudite faction. She is appointed as leader based on her high IQ score. "Jeanine Matthews is Erudite's sole representative, selected based on her IQ score. My father complains about her often (Roth, 2011: 25)". She is a smart woman. She has ability to lead the people, so she becomes the most powerful woman in her faction, Erudite. She is very ambitious about trying to fix Abnegation government or Divergent people. "On it is a picture of 
Jeanine, the Erudite representative. Her sharp-but-attractive eyes stare back at me (Roth, 2011, p. 164)". She is also described as a woman who has sharp, watery gray eyes with an attractive face. These appearances improve her performance.

On the other hand, Jeanine likes gathering knowledge because she is the leader of Erudite, the place where smart people live, even her knowledge can harm other people. She wants to help people but in the wrong way. She loves her power and does not want anyone to take it away from her. In the Erudite faction, she makes a serum, which is injected to Dauntless members, to control people into killing off every Abnegation member. "Of course. Eric said every Dauntless was injected yesterday. So now the entire faction is brain-dead, obedient, and trained to kill Perfect soldiers (Roth, 2011, p. 213)". By using the serum, Jeanine can control Dauntless member as her soldiers who will do everything she orders, but actually she feels threatened by the divergent because she cannot control them by using simulation serum. So, she makes a new experiment serum that is only injected to divergent people.

"I am not a fool," says Jeanine. "A faction of intellectuals is no army. We are tired of being dominated by a bunch of self-righteous idiots who reject wealth and advancement, but we couldn't do this on our own. And your Dauntless leaders were all too happy to oblige me if I guaranteed them a place in our new, improved government" (Roth, 2011: 219).

"Yes, improved," Jeanine says. "Improved, and working toward a world in which people will live in wealth, comfort, and prosperity" (Roth, 2011, p. 219).

These quotations show that Jeanine actually has a good purpose about her vision to make the world become a better place to live. She wants people to live in wealth, comfort, and prosperity although she has to sacrifice the other people who reject wealth and advancement, so she plans to kill Abnegation people with innocent feeling because those people reject to live in a prosperity. They are selfless people, and Jeanine hates them. She thinks that those people only make her difficult to make a better world based on her opinion. She wants all people to become wellcontrolled under her government.

Tris, Christina, Natalie, and Jeanine as the Primary Workforce in their Society

Roth writes about the country that is divided into five different factions. Each faction has their own specific category of people. There are Abnegation for selfless; Amity for the peaceful; Condor for the honest; Dauntless for the brave; and Erudite for the intellectual. When boys and 
girls are already sixteen years old, they are free to choose their own faction based on their desirability.

I stare into my own eyes for a moment. Today is the day of the aptitude test that will show me which of the five factions I belong in. And tomorrow, at the Choosing Ceremony, I will decide on a faction; I will decide the rest of my life; I will decide to stay with my family or abandon them (Roth, 2011, p. 10).

In this novel, Tris is main female character, and she is also a narrator. It is said that in the Choosing Ceremony she will choose her own faction. She can freely choose either live with her family or leaves them. She gets the same opportunity with her brother and the other men. There is no difference between boys and girls in there. The government will not forbid if they want to leave their faction and transfer to the other faction. Lorber states that women should have the same rights as men and the same educational and work opportunities (1997). According to this idea, men and women have the same rights in everything. Women should not be discriminated because of their biological weakness. Women should have the same opportunities like men.

Finally, Tris decides to choose Dauntless as her new faction. Dauntless is a faction where the initiate is trained like soldiers. Both women and men are treated in the same way. Tris tries hard during her test in Dauntless faction and fights for her strength in order to survive in there. She knows that she has no ability about being a soldier. She feels ashamed and inferior for this. However, she keeps thinking to get better progress during her train and her hard work becomes reality. She gets the best result for her training test.

In addition, there is Christina as Tris' best friend who is a transferred member too. She comes from Candor and transfers to Dauntless. She becomes Dauntless member because of her ability. In the novel, she is described as a black woman. However, she still gets the same opportunity with the other initiates. There is no different treatment between whites and blacks during the test in Dauntless. Here, she proves that skin color is not necessary in getting a good position. Zinn and Dill elaborate that within the walls constructed by race, class, and gender oppression, women of color create lives for themselves, their families, and their communities (1994). Every woman of color can freely create their own live if there is no oppression that will bind them. Therefore, they have to work hard to make their own better lives.

This also happens when Christina tries hard during her initiation test. She is successful to reach her dream to become the real member of Dauntless faction. She is at the top ten initiates. She gets the seventh rank. Becoming training initiates is a job that she wants. So that she can 
train the new initiates with all of her ability. Although, it can become funny moments when she can frighten them by pretending like an evil trainer. Here, she proves that she openly rebels against all that is white and male, and the invisible cruel system oppresses black women's individuality. In addition, not only Christina as a black woman who deserves to get her job but also Natalie who is a wife and a mother. Natalie is a good wife and a good mother too, but she also works outside home.

Natalie is not only a good wife and mother but also a good worker. She works for the government by managing city improvement projects, recruiting volunteers to administer the aptitude test, and helping the factionless with food, shelter, and job opportunities. Her job gives beneficial things to other people's lives.

"I heard there was some kind of upset with one of the tests," my mother says. Like my father, she works for the government, but she manages city improvement projects. She recruited volunteers to administer the aptitude tests. Most of the time, though, she organizes workers to help the factionless with food and shelter and job opportunities (Roth, 2011,p. 24).

Being a good woman is not only being a good mother and a good wife, but also becomes a useful person to the others. Then, a woman should have a job that she wants. Here, Natalie is working with the government to help the factionless, so it means she does not take that job to bring the family honor. She wants it because it is her own desire. She does not only become mother and wife but also women career who can help the others. Many people believe that a woman is expected to be a good mother and a good wife. Gorsky states that standard woman in patriarchal society is those who owns virtuosity, obedience toward father, and performance of being submissive wife and nurturing mother (1992). A woman needs to get wedded in order to fulfill her social requirements to be a wife and a mother. Therefore, the description of Natalie's job here proves that women can get their own decision about their job. They still can work outside the home.

Moreover, some women get a good job position because of her ability. Jeanine is one of the major main female characters who have high position in her job. She is a leader of Erudite faction. Jeanine leads her people to create serum that can control the Dauntless members by injecting it to them. Then, the Dauntless members who are already injected the serum become brain-dead. They are under Jeanine's control. It makes them doing everything such as killing and hurting other people without conscious. Erudite people accept Jeanine's order to make this 
serum because she is their leader. Besides, she is the smartest person among smart people in Erudite. "Jeanine Matthews is Erudite's sole representative, selected based on her IQ score (Roth, 2011, p. 25)". Because of her capability, she becomes greedy to control all five factions under her government by doing the bad things. She can do all these things because she is smart, so she can manage everything under her power.

\section{Feminism in Divergent Novel}

Those major female characters have shown feminism in their characterization and their social status. They have some characteristic that have reflected feminism. They are told as strong, smart, brave and resilient women. Furthermore, they have different abilities in the novel which are different from women in general. They prove that women also have powerful side because many people believe that women are always weak. They are under men's position. Beauvoir mentions that men are the Subject, and women are the Object (2011). It shows that women is the second sex because they cannot stand alone without men's help, but this novel shows different perspective of women's life.

\section{Equal Position of Women and Men in Divergent}

This novel shows how hard Tris tries to keep up with the other new initiates. Doing the dangerous things is not Tris ability. She never does those kinds of things before because in Abnegation she is just taught to be selfless person, not a brave person. She learns how to combat with the other initiates, and learns how to use gun and weapon in order to pass the initiate test. Gilman states that the male naturally fights, and naturally crows, triumphs over his rival, and takes the prize - therefore was he made male (1911). Only men can fight and do dangerous things. However, this statement is broken by Tris' situation in the novel. She also does what men do during the initiate test.

"The first thing you will learn is how to shoot a gun. The second thing is how to win a fight." Four presses a gun into my palm without looking at me and keeps walking.

$\cdots$

I stare at the weapon in my hand. Never in my life did I expect to hold a gun, let alone fire one. It feels dangerous to me, as if just by touching it, I could hurt someone (Roth, 2011, p. 47).

$$
\text { ... }
$$


"As I said this morning," says Four, "next you will learn how to fight. The purpose of this is to prepare you to act.; to prepare your body to respond to threats and challenges - which you will need, if you intend to survive life as a Dauntless (Roth, 2011, p. 50).

These quotations show that they are treated the same way, both men and women. Tris is able to learn many new things in Dauntless even those are dangerous. Firstly, she has a fight with Peter, a man who has taller body, arm muscles, and stronger than her. Tris hopes so much she can success in fighting Peter to give her best score for the initiate. As the result, she is not able to win the fight. She failed her first fight test. It is because she is still in adaptation period. She does not have combat ability before. "You don't have much muscle," he says, "which means you're better off using your knees and elbows. You can put more power behind them" (Roth, 2011, p. 50). It means Tris' weakness is her body figure because she has no muscle, but it does not mean she is weak at all. She can improve her strength during exercises. Her power is not only about her muscle but also in the way how she can manage her body to respond the threats.

Secondly, Tris has a practice to throw knives in the board. She and the other initiates are gathered in the training room. As usual, she still feels strange holding knives in her hands because she thinks that she is not allowed to hold dangerous things. However, she is actually good at this practice because she is the first person who can hit the target with all of her knives, and she defeats Peter this time. It shows that a woman can also do what men do. Throwing knives is classified as using a dangerous weapon and this skill usually belongs to man. Tris proves that she has a good skill as man does.

This condition also happens with Christina. Firstly, she has been given cruel order by Eric. She has been commanded to hang over the chasm because she wants to give up on fighting with Molly. Secondly, she is paired to $\mathrm{Al}$ on fighting practice. Christina is a woman, and $\mathrm{Al}$ is a man. It indicates that they are in the different strength because men are usually classified stronger that women.

Woman is weaker than man; she has less muscular strength, fewer red blood cells, a lesser respiratory capacity; she runs less quickly, lifts less heavy weights - there is practically no sport in which she can compete with him; she cannot enter into a fight with the male (Beauvoir, 2011, p. 68).

The statement by Beauvoir above is a proof that many people believe men have better capability in their body than women's. They always win in every aspect of power, but in this 
time, Christina breaks that statement. She is paired with Al on fighting practice. A man who is described as the largest and the broadest of all the initiates. He should win against Christina, but in fact he loses. "As expected, the next fight between Christina and Al is quick and painless. Al falls after a few hard hits to the face and doesn't get back up" (Roth, 2011, p. 94). There is also another situation that proves men actually have coward side in their selves. It is when Tris becomes better in her training test. She gets threat from ones who get jealous with her rank. "Peter, Drew, and Al were ready to throw me into the chasm out of jealousy (Roth, 2011, p. 152)". Those men try to kill Tris. It is not fair because one woman fights three men. This condition makes Tris shock, but suddenly Four comes to help Tris. Here, it can be seen that those men are actually weak. If they do not like about Tris' result, they should try harder about the test. They should not be working together to kill her. Then, it can be proven that not all men are stronger than women, and not all women are weaker than men. They also have ability to beat men even their body is smaller, or they have no much muscles.

Not only body appearance but also the way of thought that makes women are not under men's position. A woman who has a good thought and intelligence is able to be above men. They have ability to control men. Here, Jeanine is one of the major main female characters who has a highest position in Erudite. She is described as a woman who has high IQ score, so she is chosen as the Erudite leader. "Jeanine Matthews is Erudite's sole representative, selected based on her IQ score" (Roth, 2011, p. 25). Her smart brain can lead other people to follow under her control. She is good on provoking other people to believe whatever she said. She releases the news about how corrupt Abnegation is, and many people believe in that news. She can provoke the other factions to fight against Abnegation. She can order everyone under her control.

Beauvoir states that woman has always been man's slave, at least his vassal; the two sexes have never did divided the world up equally (2011). This means that women's position is based on men's will. Women are always oppressed by men in every condition. They are not capable to get their own freedom if it is not given by men. Jeanine's situation in the society proves that this statement is not in line with her position. She breaks Beauvoir argument. In the story, she becomes the most powerful woman in the society. She is able to persuade people to believe in her thought that Abnegation is a corrupt faction. Besides, she also has a lot lackeys which are men. 
One of Jeanine's lackeys, a man in a blue collared shirt and sunglasses, drives me back to the Dauntless compound in a sleek silver car, the likes of which I have never seen before (Roth, 2011, p. 185).

It shows how great Jeanine's power is. She uses men as her lackey because they have strength that can be used by Jeanine to substantiate her power. Jeanine is able to control them because she is smarter than them. They are not aware about Jeanine's cunning. All they know is how to obedient with her order. Jeanine's power breaks the statement that men always have higher position than women. They, the women, who have a profession, have high position, earn their living, and have a certain social base, will easily be as fascinating as men.

Job is very important due to position of women in the society. It is because they will get the same rights with men. No matter who they are, they should get appropriate treatment from the society. Girls, women, mothers, and wives should be treated equally with men. They cannot be intimidated because of her women's status.

In addition, in the end of the story, Natalie bravely sacrifice her life to safe her daughter, her family, and Abnegation people's lives. She fights with guards who arrest Tris.

"Go to your father and brother. The alley on the right, down to the basement. Knock twice, then three times, then six times." She cups my cheeks. Her hands are cold; her palms are rough. "I'm going to distract them. You have to run as fast as you can."

I feel her lips on my forehead and then she runs into the middle of the street. She holds her gun above her head and fires three times into the air. The Dauntless start running.

I sprint across the street and into the alley. As I run, I look over my shoulder to see if any Dauntless follow me. But my mother fires into the crowd of guards, and they are too focused on her to notice me (Roth, 2011, p. 226).

She tells Tris to run going to her father and brother in a safer place. Then, Natalie will distract them. She wants to make sure that Tris will be safe. It does not matter to her even she knows she may get killed by the guards. This shows that even Natalie is a woman, she can handle the harm that she faces by her own self. She does not need her beloved ones going along with her to face danger. She will do everything to make Tris, her family, and people in Abnegation to be safe. This condition breaks Beauvoir's argument. Beauvoir mentions that "He is the Subject; he is the Absolute. She is the other" (2011, p. 26). Men actually are the important part in fighting or in war because they are the subject, so their superiority should be shown. Men 
are built for more challenging than women. Being the Subject means that they have physical attributes that help them succeed in some areas that women are inferior in, but it does not mean that women cannot do those things. Women are just capable as men to do anything. Both men and women have their own physical attributes that help them to do something better than the opposite sex.

"There are men with guns up there. When they see me, they will kill me, if they can," I tell my father quietly. I search his eyes. "Should I let them?"

He stares at me for a few seconds.

"Go," he says, "and God help you."

I climb the stairs carefully, stopping just before my head emerges. I wait, watching the shadows move, and when one of them stops, I step up, point my gun, and shoot (Roth, 2011, p. 238).

It shows that Tris is able to protect three men in that time. She becomes a heroine for them. She has special achievements and personal qualities, so they are belief in her to handle the guards, although she has lost her father after all. He died shot by the Dauntless armies, but this situation does not make Tris giving up. She does not want to waste too much time to cry over her father. Because for every second she wasted, it will make another Abnegation member dies. She still put back into saving insane people's lives, so she cannot give up now. She will stop the simulation, so that Dauntless members who are under its control will be free and conscious again. It also can make Abnegation will not be shot by them, so those people become safe.

Then, in the end of her fight, she successes to destroy the simulation. She saves many insane people from the danger. She gets the good result from her hard work. Now, she is not inferior woman. She is a heroine who saves the city from the war. She has proven that women can do great useful things to the world. "Women's actions have never been more than symbolic agitation; they have won only what men have been willing to concede to them; they have taken nothing; they have received (Beauvoir, 2011, p. 28)". This statement argues that all actions that has been done by women is nothing. It does not mean significant things. However, Tris', Natalie's, Christina's, and Jeanine's actions are not given by anyone. They accept what they have been done. They do everything based on their free will. There is no man that influences their action. 
Women's Independence in Divergent

Women also have the same rights and the same ability with men. They can live independently without men's control. Here is Tris. She is a common girl who was born in Abnegation faction. She has a father named Andrew Prior, a mother named Natalie Prior, and a brother named Caleb Prior. In the first story of the novel, she is described as sixteen years old girl who will participate on aptitude test. She is in the process of choosing her own future faction because she is already sixteen years old. She gets her freedom to choose what faction she wants in the Choosing Ceremony. She can choose between staying with her parents in Abnegation or leaving them for the other factions.

Her choice is not influenced by her father, mother, or the other people. Her choice is based on her ability that has been checked in the aptitude test. Everybody is not allowed to share the result of aptitude test including Tris. So that she can choose wise about her future faction. It shows boys and girls are in the same situation. There is no different treatment between them. Either girls or boys have the same opportunity about their own choices. They are given the same right.

Tris who already knows that she has inconclusive result of aptitude test, which are Abnegation; Dauntless; and Erudite, chooses Dauntless as her new faction. She decides to leave her family in Abnegation. At that time, her father as a man who owns Tris cannot do anything because his right through Tris is over. Here, the society believes in a vision faction before blood. It means that faction is above all else including family. No one can bind them if they have already decided their choice. This also happens with Tris. She can choose freely to transfer in Dauntless without protested by anyone.

Besides, Natalie Prior, who is Tris' mother and Andrew's wife, is one of the good examples of feminism in this novel. Although she is a mother and wife, she still has a job outside the house. She works with the government. According to Beauvoir,

Women were not socially equal to men; taking part in religion and government, they could have the role of regent, but the pharaoh was male; priests and warriors were males; woman's role in public life was secondary one; and in private life, fidelity was required of her without reciprocity (2011, p. 122).

Women are not appropriate to be given a job to manage the government. They are just the secondary part of the society. All of the important work for the society is given to male because they are believed more capable to work than women. In line with Beauvoir statement, Madsen 
also mentions that woman should be confined to the domestic sphere, nurturing children, maintaining the household and serving their husbands (2000). This means that women's job is only in the home. They should become a good mother and a good wife. Their job is to take care of their children, cook the food for their family, become obedient to their husband, and manage house work by themselves. However, Natalie, also a mother and wife, is not classified as women who is mentioned before. She has a job outside home. She is not only taking care of her family but also working with the government.

It means that Natalie's depiction in the novel is not in line with Beauvoir statement. She has an equal position with men. She is permitted to have a job out of her house work. Her husband does not forbid her to work with the government. She is allowed to help factionless and manage city improvement projects. All she does is to help the other people. However, she still does not leave her responsibility to her family. She becomes a mother who is taking care of her children, and a wife who is serving her husband. She can balance all her works.

\section{Conclusion}

Divergent novel is written by Veronica Roth. This novel portrays a post-apocalyptic society which divides it into five different factions. The novel tells about women who have different characterizations, but their characterizations in this novel show strong sides of women. They have their own abilities which are different with women in general. Those major female characters are Tris, Natalie, Christina, and Jeanine. The statements and ideas in the novel describe the way of those major female characters shows their feminism.

The novel is analyzed using Rene Wellek's theory which emphasizes to find the characterization of major female characters in the novel. The concept of feminism by Simone de Beauvoir is also used to reveal how the major female characters get the same social status and how they reflect feminism in the novel. This novel describes that feminism can be represented through behaviors, power, and desire.

The analysis shows major female characters have reflected feminism. Tris and Christina have strong character. They become the real Dauntless faction who have combat ability. They are able to use dangerous things during the initiate test and to defeat men in combat test. They are not weak, and they show their strength through the initiation test. Then, Natalie shows her bravery as Tris' mother. She does everything to keep her children to be safe even she has to 
sacrifice her own self. The characterization of Natalie is categorized as a brave woman. Besides, women also can have control and power through men. It is proved by Jeanine's characterization. She is very smart, so she can become a leader in Erudite faction. She has full power to control people in there.

Furthermore, those major female characters can have the same opportunity in the society. They have the same rights with men to become what they want. Their social status is not discriminated by the others. Tris and Christina can freely choose their own faction. They decide to transfer to Dauntless, and no one can forbid them because they have rights to choose that. Moreover, Natalie also have job outside the house even she is a mother and a wife. She does not only take care of her family but also work in the government to help other people. It shows that she has the same chance with men in getting the job. Women are permitted to participate in the government. Here, Jeanine also has a great job. She is a leader, so she manages all of her people in Erudite. She has power to control them. It shows that her social status is higher than the other men.

Those major female characters are made in very positive angle by the author. She shows her support to the major female characters in the story by exposing their bravery, cleverness, and strength. Their superiorities have given understanding to the readers that those major female characters in the novel are not weak as women's portrait by a lot of people. They also cannot be categorized as the second sex like what is said by Beauvoir. They are not live under men's control because they independently stand on their own choice. They give a new perspective of woman character in the literary works. It is obviously different from the woman stereotyping in the literary works. Tris, Christina, Natalie, and Jeanine have given new paradigm that women characters can have equal rights with men. It can give new inspiration for the women readers to see the values of being strong woman.

\section{References}

\section{Books:}

De Beauvoir, Simone. 2011. The Second Sex. New York: A Division of Random House, Inc., https://nashvillefeministart.files.wordpress.com/2014/06/1949_simone-de-beauvoir-thesecond-sex.pdf, retrieved on Saturday, 9 January 2016.

Gilman, C. P. 1911. The Man-Made World. New York: Charlton Company.

Gorsky, S. R. 1992. Feminity to Feminism and Literature in the Nineteenth Century. New York: Twayne Publisher. 
Harrison, Martin. 1998. The Language of Theatre. London: Routledge.

Lorber, Judith. 1997. The Variety of Feminisms and their Contribution to Gender Equality. Oldenburg University.

Madsen, Deborah L. 2000. Feminist Theory and Literary Practice. Sterling, Virginia: Pluto Press.

Roth, Veronica. 2011. Divergent. United States of America: HarperCollins Publishers LLC, http://www.lake.k12.fl.us/cms/lib05/FL01000799/Centricity/Domain/4432/Divergent\%20 Book\%201\%20Veronica\%20Roth.pdf, retrivied on Friday, 20 March 2015.

Tyson, Lois. 2006. Critical Theory Today A User-Friendly Guide (Second Edition). New York: Routledge.

Wellek, Rene and Warren, Austin. 1977. Theory of Literature. United States of America: Harcout, Brace, and Company, Inc.

Wollstonecraft, Mary. 2000. Vindication of the Rights of Woman (Renascence Editions). University of Oregon.

Zinn, Maxine Baca and Dill, Bonnie Thornton. 1994. Women of Color in U.S. Society. United States of America: Temple University Press.

\section{Internet:}

https://en.m.wikipedia.org/wiki/Apocalyptic_and_post apocalyptic_fiction, retrieved on Tuesday, 22 November 2016). 